\title{
DISTRIBUTION OF AMPHIBIANS IN THE ISOLATED FOREST \\ PATCHES AND OTHER HABITATSOF THE HANTANA RANGE, PERADENIYA
}

\author{
IV M P K Samarawickrama, 2 V Chandrasegaran, \\ and $1 K B$ Ranawana \\ 'Department of Zoology, University of Peradeniya \\ 2 PGIS, University of Peradeniya
}

Sri Lanka is blessed with a diverse amphibian fauna, and the island harbors 54 recorded amphibian species.

Five major habitat types namely Grasslands, Natural isolated forest patches, Riverine vegetaion, Pinus plantations, and abandoned tea land in the Hantana range was surveyed for six months from June 2003 to November 2003. Day and night-time survey was carried out to locate amphibian and to record their microhabitats. Line transect was used in the field and hand nets were used to catch the amphibians. Species identification was done in the field used standard guides and photographs of amphibians were taken whenever necessary.

Seventeen amphibian species ( $31 \%$ of the total) including ten endemics were recorded from the five sites during the survey. Highest number of species (13) was recorded from the Riverine vegetaion. Natural isolated forest patches held the second highest number of species (10). The number of species in the Riverine vegetation represents $24 \%$ of the total number present in the country. Philautus fergusonianus, Rhacophorus macropus, Rhacophorous reticulatus, Rhacophorous cavirostris, and Microhyla ornate were recorded for first time in the site.

Hantana Range and the University land are subjected to severe degradation due to human activities. The natural forests have reduced to a greater extent due to the illegal felling, and the grasslands and Pinus plantations are subjected to annual fires. Many sites wcre identified with severe human interruption due to hiking and other re-creative activities and other domestic usages. Therefore, the most amphibian species found in the region are heavily threatened.

\footnotetext{
Proceedings of the Ninth Annual Forestry and Environment Symposium 2003 of the Department of Forestry and Environmental Science, University of Sri Jayenwandenepura, Sri Lanka
} 